\title{
The genetic structure of phenologically differentiated Large Blue (Maculinea arion) populations (Lepidoptera: Lycaenidae) in the Carpathian Basin
}

\author{
Judit BERECZKI, JÁnos P. TÓTH, ANDREa TÓTH, Edit BÁTORI, Katalin PECSENYE and ZoltÁn VARGA
}

Department of Evolutionary Zoology and Human Biology, Institute of Biology and Ecology, University of Debrecen, Debrecen, P.O.B. 3, H-4010, Hungary; e-mail: bereczki.judit@gmail.com

Key words. Lycaenidae, genetic structure, phenological isolation, Maculinea arion, "spring arion", "summer arion”, enzyme polymorphism

\begin{abstract}
The infraspecific taxonomy of the European populations of the Large Blue (Maculinea arion) is confusing. Several subspecies have been described mostly based on external morphological features. In the Carpathian Basin two subspecies have been distinguished. Maculinea arion arion flies from mid-May to mid-June and Maculinea arion ligurica is on the wing from the end of June to mid-August. The two forms show some differentiation in habitat use, but occasionally can also share habitats with two peaks in the appearance of butterflies. Our aim was to study the level and structure of genetic variation in a set of populations of the two phenologically different M. arion. Imagos were collected from 8 localities between 2000 and 2006. Enzyme polymorphism was analysed at 13 enzyme loci using polyacrylamide gel electrophoresis. In the analysis of the data, we estimated the parameters of polymorphism. To study the pattern of genetic differentiation F-statistics, hierarchical F-statistics and AMOVA were computed. GeneClass and Structure were both applied to analyse the differentiation between the two phenologically different sets of populations. Cavalli-Sforza and Edwards' arc distances were calculated and a UPGMA dendrogram was constructed on the basis of the distance matrix. PCA analysis was also carried out using the allele frequencies of the individuals. The level of polymorphism was relatively high in $M$. arion. The results of all analyses indicated that the differences between the two sets of phenologically different populations accounted for a low percentage of the total differentiation. In addition, a sizeable amount of variation could be attributed to the differences among the samples collected from the same population in consecutive years. Thus, we concluded that the "spring" and "summer arion" could not be considered as separate ESUs, although we could attribute conservation value to both forms on the basis of their phenological differentiation and habitat use.
\end{abstract}

\section{INTRODUCTION}

Maculinea Van Eecke, 1915* (Lepidoptera: Lycaenidae) species are the most intensively studied group of Palearctic butterflies due to their very special social parasitic life cycle and also owing to the severe decrease and fragmentation of their habitats. Numerous Western conservation biologists regard them as "flagship" species (Anonymus, 1993). Simultaneously they are also umbrella species (Shrader-Frechette \& McCoy, 1993; Lambeck, 1997; New, 1997; Fleishman et al., 2005; Spitzer et al., 2009) representing the needs of other species through their special and complex habitat requirements. During their development they need particular food plants and host ant species. Their early larval instars feed on the seeds of their initial food plant(s) as mono- or oligophagous feeders. However, they gain only a little weight in this period (Elmes et al., 1991a, b; Thomas \& Wardlaw, 1992). After 2-3 weeks larvae drop to the ground and wait for foraging ant workers (mostly Myrmica Latreille, 1804), who find and drag them to their nests (Pueefoy, 1953; Thomas, 1976). In the next stage of development they follow either a "predatory" or "cuckoo" strategy in the nests for 10-11 months (Thomas et al., 2000), gaining approximately $98-99 \%$ of their final body weight (Elmes et al., 1991a). After pupation imagos emerge from the nest. These special habitat requirements result in their vulnerability (Settele \& Kuhn, 2009).

In the last few decades all Maculinea species have experienced severe declines over most of their ranges (Thomas, 1995; Wynhoff, 1998). One of the most spectacular declines was shown by Large Blues - Maculinea arion (Linnaeus, 1758). The species became extinct in the Netherlands in 1964 (Tax, 1989), in the UK in 1979 (Thomas, 1995) and in Belgium in 1996 (although later the species was reintroduced into the UK and it also recolonized Belgium) (Goffart, 1997; Thomas et al., 2009). It shows serious regression all over Europe, especially on the northern border of the distribution area of the species (Wynhoff, 1998). Large Blues are endangered on a European scale. The species is listed in the IUCN Red List of Threatened Species as "near threatened" and it is included in Annex IV of the European Habitats' Directive (Munguira \& Martin, 1997; Van Swaay et al., 1998).

The taxonomic status of Large Blue populations in Central and Western Europe is confusing. Several subspecies have been described mostly on the basis of external morphological features such as light silvery blue vs. dark violet-blue colouration or black maculation of wings. In

\footnotetext{
* Here we follow the recommendation of Balletto et al. (2010) concerning the generic names Maculinea Van Eecke, 1915 vs. Phen-
} garis Doherty, 1891. 


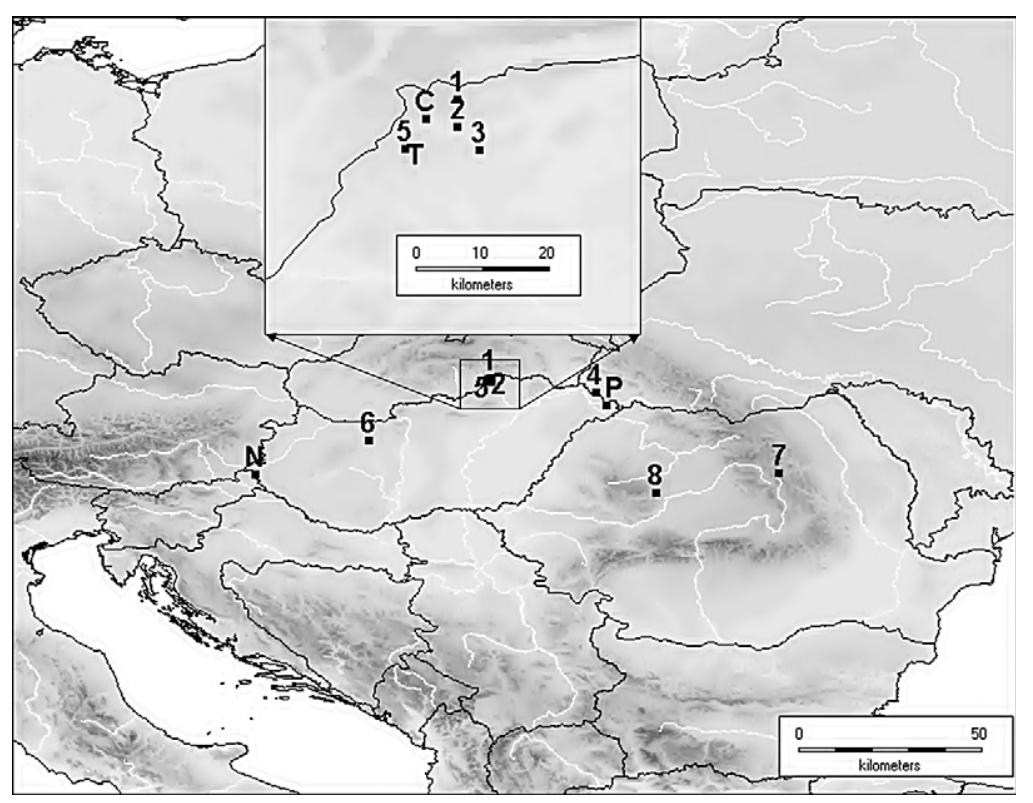

Fig. 1. Sample sites. M. arion "spring type": 1 - Jósvafö-plateau; 2 - Jósvafö-Szőlöhegy; 3 - Teresztenyei-plateau. M. arion "summer type": 4 - Kaszonyi-hill; 5 - Aggtelek; 6 - Vérteskozma; 7 - Lake Gyilkos; 8 - Torockószentgyörgy. Outgroups: P - M. alcon "pneumonanthe type", Fülesd; C - M. alcon "cruciata type", Jósvafo-Tohonya; T - M. teleius, Aggtelek; N - M. nausithous, Szomoróc.

the Carpathian Basin M. arion has considerable morphological variation and several subspecific taxa have been named (Szabó, 1956; Gozmány, 1968). Following Bálint (1996) generally two subspecies (or even species) have been distinguished. Maculinea arion arion (Linnaeus, 1758) (see below as "spring type arion") flies from mid-May to mid-June and prefers short-grass dry swards with cushions of early flowering Thymus species (Th. serpyllum L., Th. pannonicus All. and related species), which serve as initial food plants. Maculinea arion ligurica (Wagner, 1904) (see below as "summer type arion") is on wing from the end of June to mid-August and mostly occurs at xerothermic oak forest fringes, on woodland clearings and in fen-like habitats in hilly areas. Females oviposit among flower-buds of late-flowering Thymus species (mostly Th. pulegioides L.) and/or Origanum vulgare L. Hitherto no evidence has been found concerning the genetic or reproductive isolation between the two forms (Munguira \& Martin, 1997). Although the two forms locally share habitats (Varga, 2003; Tóth \& Bereczki, pers. obs.) their syntopic populations are morphologically and phenologically differentiated. Our knowledge on the host ant use of the two subspecies is insufficient. Myrmica sabuleti Meinert, 1861 is known to be the main host ant of M. arion in Western Europe and it was also found as a putative host ant in some $M$. arion habitats in Hungary (Tartally, 2008). Thus, the taxonomic status of these two subspecies is fairly uncertain, in a similar way to the case of the $M$. alcon species group (Als et al., 2004; Pech et al., 2004; Bereczki et al., 2005; Fric et al., 2007; Pecsenye et al., 2007). Despite the conservational significance of the two phenologically and ecologically different forms, former genetic and morphometric studies (Als et al., 2004; Pech et al., 2004; Fric et al., 2007) did not concern them. Therefore, our goal was to study genetic variation in phenologically different $M$. arion populations.

In addition, we wanted to know whether these taxa represented separate Evolutionary Significant Units (ESUs). Numerous definitions of ESU exist (Ryder, 1986; Dizon et al., 1992; Vogler et al., 1993; Moritz, 1994; Waples, 1998; Paetkau, 1999). The majority of these definitions suggest that an ESU should be geographically discrete and show divergence of both molecular and nonmolecular traits (Ryder, 1986; Dizon et al., 1992; Vogler et al., 1993). In fact, the ESU concept has different components, namely reproductive and historical isolation as well as adaptive distinctiveness (Crandall et al., 2000).

Therefore, the aims of our study were: (i) to estimate the level of genetic diversity of $M$. arion; (ii) to reveal the structure of genetic variation, particularly the differentiation between the "spring" and "summer type" of $M$. arion; (iii) to determine whether these taxa represent separate Evolutionary Significant Units (ESUs). The story of Large Blues in the UK demonstrated that the detailed ecological, demographic and genetic knowledge on the species in question is the pre-requisite of a successful conservation strategy. Thus, we feel that our results will contribute to the successful conservation of $M$. arion in the Carpathian Basin.

\section{MATERIAL AND METHODS}

\section{Sampling}

Altogether 21 samples were collected from 8 populations between 2000 and 2006 in Hungary and Romania (Appendix 1, Fig. 1). Of the 8 populations 3 were "spring type" and 5 were "summer type" M. arion. Populations of all the other four Maculinea taxa were used as outgroups (Appendix 1, Fig. 1). Imagos were collected at the end of the egg laying period and 
stored at $-80^{\circ} \mathrm{C}$ until electrophoresis. Sample sizes varied between 11 and 59 .

\section{Molecular analyses}

Allozyme polymorphism was studied at 13 loci (see Table 2) by vertical polyacrylamide gel electrophoresis. Thoraxes homogenized in $300 \mu$ l of extraction buffer were used to study $G p d h$, G6pgdh, Hk, Idh, Mdh, Me, Pgi, Pgm and Sod. Abdomens homogenized in $200 \mu \mathrm{l}$ of extraction buffer were used to analyse Acon, Acph, Aox and Est. The extraction buffer, the electrophoresis buffer systems and running conditions, together with the staining solutions were used according to Bereczki et al. (2005). Genotypes of the individuals were scored according to their enzyme pattern

\section{Statistical analyses}

Parameters of polymorphism (average number of alleles per locus, proportion of polymorphic loci, average observed heterozygosity, average number of multi-locus genotypes, total number of alleles and distribution of alleles) were calculated for each population. Genetic differentiation among the populations was first analysed by Wright's F-statistics (Wright, 1978; Weir, 1996). In this analysis, the distribution of genetic variation is characterised by three indices $\left(\mathrm{F}_{\mathrm{IT}}\right.$ - total variation, $\mathrm{F}_{\mathrm{IS}}$ - within population variation and $\mathrm{F}_{\mathrm{ST}}$ - between population variation). The analyses were computed by using Fstat ver. 1.2 (Goudet, 1995). An exact test for population differentiation (Raymond \& Rousset, 1995a) was also conducted to test for independence of the allelic composition of the populations. Genepop ver. 1.0 (Raymond \& Rousset, 1995b) was used to perform this test. Indices of differentiation ( $\mathrm{F}_{\mathrm{ST}}$, average Cavalli-Sforza and Edwards' arc distances, frequency of private alleles and standard deviation of allele frequencies) were calculated for "spring" and "summer type", respectively.

The distribution of the total genetic variation at various levels of the hierarchy was also studied by AMOVA (Excoffier et al., 1992; Weir, 1996). In this analysis, the total genetic variation was partitioned into the following components: among groups (i.e. putative subspecies), among populations within a group, among samples within populations and among individuals within samples. AMOVA was carried out by Arlequin ver 2.000 (Schneider et al., 2000).

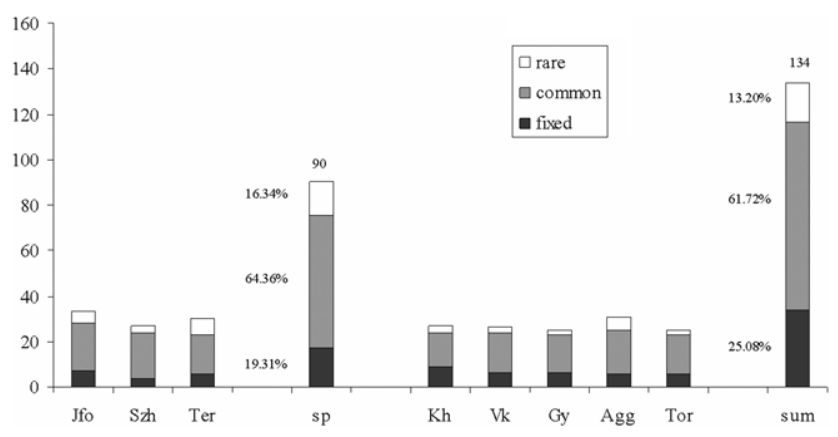

Fig. 2. Total number and the distribution of alleles in populations and in the case of $M$. arion "spring type" (sp) and "summer type" (sum), respectively. Categories: rare: $\mathrm{p}<0.05$; common: $0.05<p<1$; fixed: $p=1$. For the abbreviations of the populations see Appendix 1 .

The genetic structure of the populations was also analysed by the Bayesian-clustering method. Here, we estimated the most probable number of genetically differentiated groups $(\mathrm{K})$ in our samples and assigned the individuals to these groups. Structure 2.3.2 was run to carry out these analyses with an initial burn in 30,000 and a running length of 150,000 (Pritchard et al., 2000).

Allele frequencies were used to estimate Cavalli-Sforza \& Edwards' (1967) arc distances and an UPGMA dendrogram (Sneath \& Sokal, 1973) was constructed on the basis of the distance matrix using Biosys-1, Release 1.7 (Swofford \& Selander, 1981).

In the last part of the study, a principal component analysis (PCA) was conducted using the allele frequency data of the individuals to reveal the relationship between the previously sorted groups (putative subspecies). PCA analyses were performed using Past ver. 1.56 (Hammer et al., 2001).

Finally, we carried out an assignment test. In this test log likelihood values were calculated for each individual multilocus genotype for all the samples on the basis of the expected distribution of genotype frequencies of the respective sample (Paetkau et al., 1995). Using these values we assigned each individual to the most probable sample. The computation of the assignment test was performed by GeneClass2 (Piry et al., 2004).

TABLE 1. Parameters of polymorphism. $\mathrm{N}$ - sample size; $\mathrm{n}_{\mathrm{A}}$ - average number of alleles per locus; $\mathrm{P}$ - proportion of polymorphic loci; $\mathrm{H}$ - average observed frequency of heterozygotes; $\mathrm{G}$ - average number of multilocus genotypes.

\begin{tabular}{lcccccc}
\hline Taxa & Population (No.) & $\mathrm{N}$ & $\mathrm{n}_{\mathrm{A}}$ & $\mathrm{P}$ & $\mathrm{H}$ & $\mathrm{G}$ \\
\hline & Jósvafö-plateau (5) & 23.6 & 1.9 & 41.6 & 0.154 & 0.925 \\
M. arion "spring type" & Jósvafö-Szőlöhegy (1) & 15.7 & 2.1 & 53.8 & 0.167 & 1.000 \\
& Teresztenyei-plateau (2) & 20.1 & 2.1 & 53.8 & 0.148 & 0.902 \\
& Total (8) & 21.7 & 2.0 & 46.2 & 0.154 & 0.864 \\
\hline & Kaszonyi-hill (4) & 15.4 & 1.6 & 34.6 & 0.131 & 0.778 \\
& Vérteskozma (2) & 15.3 & 1.7 & 46.2 & 0.170 & 0.871 \\
M. arion "summer type" & Lake Gyilkos (2) & 19.7 & 1.7 & 46.1 & 0.169 & 0.950 \\
& Aggtelek (4) & 24.0 & 2.0 & 53.8 & 0.165 & 0.845 \\
& Torockószentgyörgy (1) & 16.9 & 1.9 & 53.8 & 0.160 & 0.941 \\
M. arion & Total (13) & 18.8 & 1.8 & 45.6 & 0.156 & 0.810 \\
M. alcon "pneumonanthe type" & Total (21) & 19.9 & 1.9 & 45.8 & 0.155 & 0.767 \\
M. alcon "cruciata type" & Fülesd (1) & 23.6 & 1.3 & 23.1 & 0.093 & 0.833 \\
M. alcon & Jósvafo-Tohonya (1) & 34.1 & 1.9 & 38.5 & 0.141 & 0.857 \\
M. teleius & Total (2) & 28.9 & 1.6 & 30.8 & 0.117 & 0.797 \\
M. nausithous & Aggtelek (1) & 57.1 & 2.1 & 38.5 & 0.111 & 0.542 \\
\hline
\end{tabular}


TABLE 2. Results of F-statistics and exact test of population differentiation computed for all 21 samples regardless of the putative subspecies they belong. $\mathrm{F}_{\mathrm{IT}}-$ total genetic variation; $\mathrm{F}_{\mathrm{ST}}$ - variation among populations; $\mathrm{F}_{\mathrm{IS}}$ - variation within populations; ns - not significant; * $0.00077<\mathrm{p}<0.0038$; *** $\mathrm{p}<$ 0.000077 (after Bonferroni's correction based on 13 loci).

\begin{tabular}{lcccc}
\hline Locus & $\mathrm{F}_{\mathrm{IT}}$ & $\mathrm{F}_{\mathrm{ST}}$ & $\mathrm{F}_{\mathrm{IS}}$ & Exact test \\
\hline Acon & $0.407^{*}$ & $0.186^{*}$ & $0.272^{*}$ & $* * *$ \\
Acph & $0.220^{*}$ & $0.086^{*}$ & $0.146^{*}$ & $* * *$ \\
Aox & $0.440^{*}$ & $0.312^{*}$ & $0.186^{*}$ & $* * *$ \\
Est & 0.128 & 0.009 & 0.120 & $\mathrm{~ns}$ \\
G6pdh & -0.002 & -0.002 & -0.001 & $\mathrm{~ns}$ \\
Gpdh & -0.007 & 0.028 & -0.035 & $*$ \\
Hk & 0.087 & $0.041^{*}$ & 0.048 & $* * *$ \\
Idh & -0.067 & 0.010 & -0.078 & $\mathrm{~ns}$ \\
Mdh & 0.000 & 0.000 & 0.000 & $\mathrm{~ns}$ \\
Me & -0.001 & 0.000 & 0.000 & $\mathrm{~ns}$ \\
Pgi & 0.086 & 0.023 & 0.065 & $*$ \\
Pgm & $0.146^{*}$ & $0.081^{*}$ & 0.071 & $* * *$ \\
Sod & 0.000 & 0.016 & -0.016 & $\mathrm{~ns}$ \\
All loci & $0.241^{*}$ & $0.137^{*}$ & $0.120^{*}$ & $* * *$ \\
\hline
\end{tabular}

\section{RESULTS}

Alternative alleles occurred at all loci in at least one sample. M. arion exhibited the highest level of polymorphism of all sampled Maculinea species: the portion of polymorphic loci was $45.8 \%$ and the average observed frequency of heterozygotes was 0.155 . The parameters of genetic variation indicated a slightly higher level of polymorphism in the "spring type" than in the "summer type" populations (Table 1). A similar tendency was observed in the distribution of alleles (Fig. 2). The proportion of rare alleles was slightly higher, while that of the fixed alleles was smaller in the "spring arion" samples than in the "summer type" ones. The total number of alleles was much higher in the "summer arion" than in the "spring type" (Fig. 2) but this could have been the consequence of larger sample sizes (Appendix 1).

The results of F-statistics indicated that a relatively high portion of variation was explained by the differences among the samples (Table 2: $\mathrm{F}_{\text {IT }}$ ). Nevertheless, only 5 loci of the total 13 proved to be significantly differentiating (Table 2: $\mathrm{F}_{\mathrm{ST}}$ ). At the same time, the results of the exact test showed that the samples were significantly differentiated at seven loci (Table 2: exact test). The within population variation was also sizeable. Although the

TABLE 3. Indices of differentiation. $\mathrm{F}_{\mathrm{ST}}$ - variation among populations; D - Cavalli-Sforza and Edwards' arc distances; $\mathrm{q}-$ frequency of private alleles; $\mathrm{s}_{\mathrm{p}}-$ standard deviation of allele frequencies. $* 0.00077<\mathrm{p}<0.0038$ (after Bonferroni's correction based on 13 loci).

\begin{tabular}{lcccc}
\hline & $\mathrm{F}_{\mathrm{ST}}$ & $\mathrm{D}$ & $\mathrm{q}$ & $\mathrm{s}_{\mathrm{p}}$ \\
\hline M. arion "spring type" & $0.076^{*}$ & 0.161 & 0.032 & 0.091 \\
M. arion "summer type" & $0.159^{*}$ & 0.211 & 0.034 & 0.112 \\
\hline Total & $0.137^{*}$ & 0.205 & 0.036 & 0.110 \\
\hline
\end{tabular}

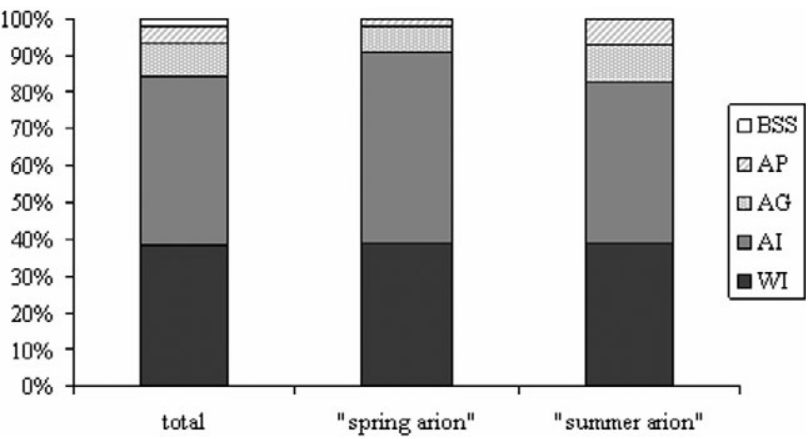

Fig. 3. The distribution of variation at different levels of the hierarchy (AMOVA). Levels of hierarchy: BSS: between the putative subspecies; AP - among populations; AG - among generations originated from the same population; AI - among individuals; WI - within individuals.

average $F_{I S}$ value suggested significant heterozygote deficiency this was only attributable to 3 loci (Table 2: $\mathrm{F}_{\text {IS }}$ ).

The fixation index (Table 3: $\mathrm{F}_{\mathrm{ST}}$ ) showed significant differentiation both among the "spring" and "summer arion" samples. $F_{\mathrm{ST}}$ values and Cavalli-Sforza and Edwards' arc distances suggested a slightly higher level of differentiation among the "summer arion" than among the "spring type" populations (Table 3: $\mathrm{F}_{\mathrm{ST}}$ and D). However, it is important to note that we had more "summer arion" than "spring type" samples. Moreover, the "summer arion" originated from several geographical regions. The other two measures of differentiation (frequency of private alleles and standard deviation of allele frequencies) were similar in the two types (Table 3: $q$ and $s_{p}$ ).

The results of AMOVA showed the distribution of the total sample variation between the spatial and temporal components (Fig. 3). The spatial component could be further divided into two parts: variation between the putative subspecies (Fig. 3: BSS) and variation among the populations within the subspecies (Fig. 3: AP). The differences between the two subspecies accounted for a lower portion of the total level of differentiation than that among populations. The temporal component of variation indicated a sizeable level of differentiation among the samples/generations collected from the same population (Fig. 3: AG). Most of the total genetic variation was attributable to the variation among the individuals (Fig. 3: AI). We also carried out AMOVA in the case of the "spring" and "summer arion", respectively (Fig. 3). Both the spatial and the temporal component of variation (Fig. 3: AP and AG) proved larger in the "summer arion" samples than in the "spring type" ones. Probably it arose from partly larger sample sizes of the "summer arion" and partly the fact that the "summer arion" samples originated from four geographical regions located at larger distances from each other. In contrast, fewer "spring type" samples originated from the same region (Fig. 1).

We also analysed the differentiation between the putative subspecies using Structure (Fig. 4). The most probable number of genetically differentiated groups $(\mathrm{K})$ in our samples was $3(\operatorname{LnP}(\mathrm{D})=-3797.5, \operatorname{Var}[\operatorname{LnP}(\mathrm{D})]=$ $\left.454.4, \mathrm{a}_{1}=0.0695\right)$. The "spring" and the "summer arion" 


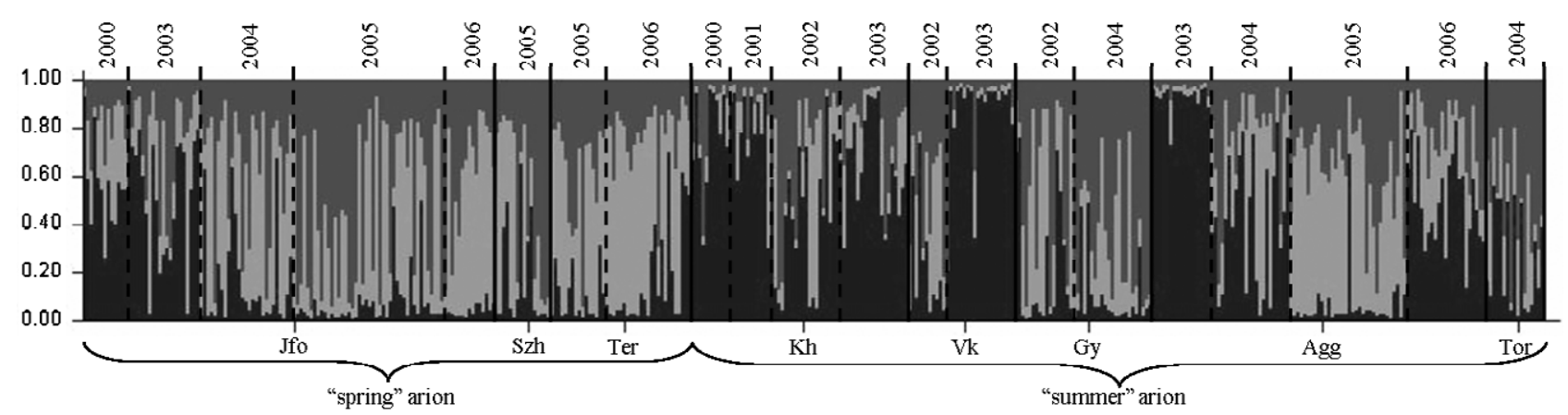

Fig. 4. The results of Structure analysis.

did not separate clearly from one another. The "spring arion" samples showed a more homogenous pattern than those of the "summer arion", in the case of which periodically recurring patterns could be observed. Probably all this originated from the fact that the sample sites of the "spring arion" were located in the same geographic area (Fig. 1). On the contrary, the "summer arion" samples were collected in four geographic regions a long distance apart. Therefore, the combination of the spatial and tem-
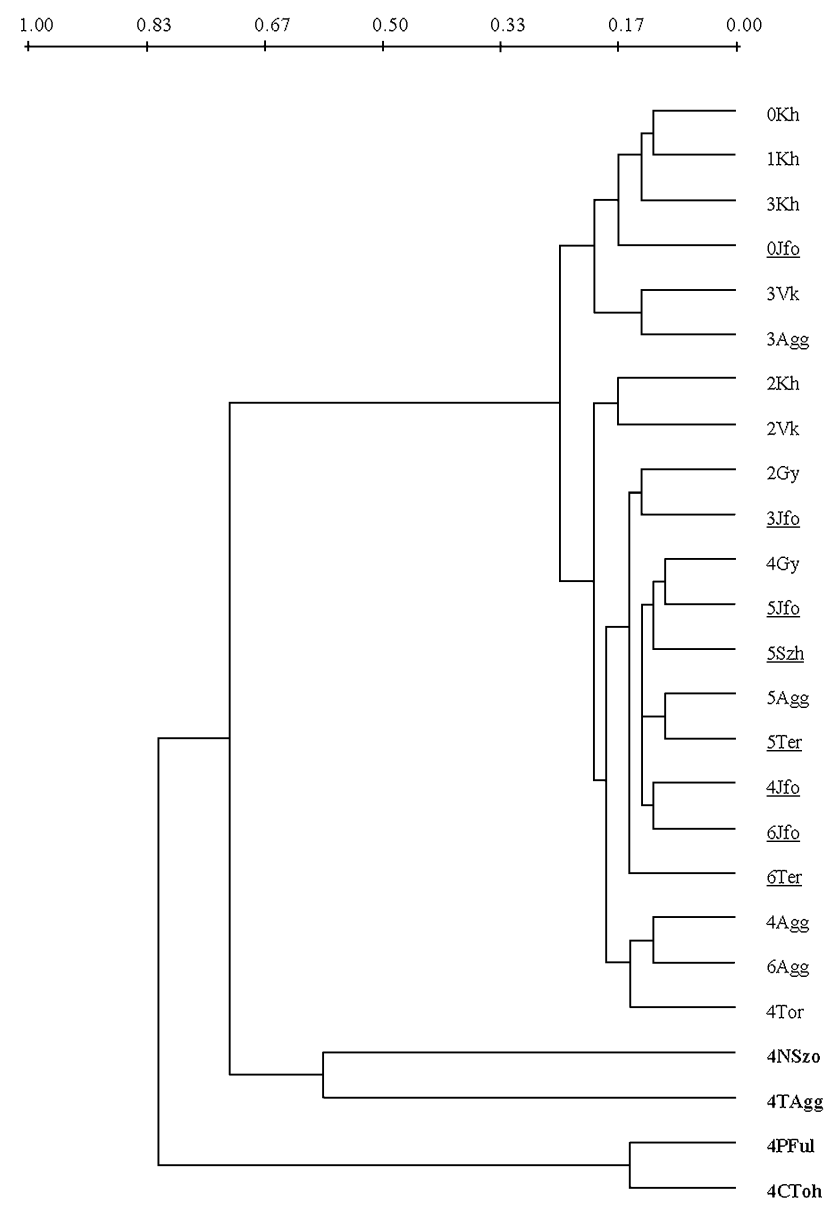

Fig. 5. Dendrogram (unweighted pair group method with arithmetic mean) constructed on the basis of Cavalli-Sforza and Edwards' arc distances. Outgroups were marked with bold style. Samples of M. arion "spring type" are underlined. For the abbreviations of the populations see Appendix 1. Numbers before abbreviations indicate the year of sampling. poral variation may have generated larger differences among the "summer arion" samples similarly to the results of AMOVA (see previously).

Cavalli-Sforza and Edwards' genetic distances were calculated and an UPGMA dendrogram was constructed on the basis of the distance matrix, which also included all the examined Maculinea species (Fig. 5). The samples of the two different putative subspecies were randomly scattered on the dendrogram. The scale of differentiation between the two types was similar to that of two types of M. alcon ([Denis \& Schiffermüller], 1775). Earlier the latter two forms were generally treated as two distinct species based on the different initial food plants and host ant species (Elmes \& Thomas, 1987a, b; Thomas et al., 1989; Elmes et al., 1991a, b, 1994; Munguira \& Martin, 1997). However, recent studies suggested that those represented just local ecological adaptations (Als et al., 2004; Pech et al., 2004; Bereczki et al., 2005; Fric et al., 2007; Pecsenye et al., 2007). At the same time, it is remarkable that the samples originating from the same population but collected in different years (generations) were not always clustered together. These findings are in good agreement with the results of Structure and AMOVA (see previously).

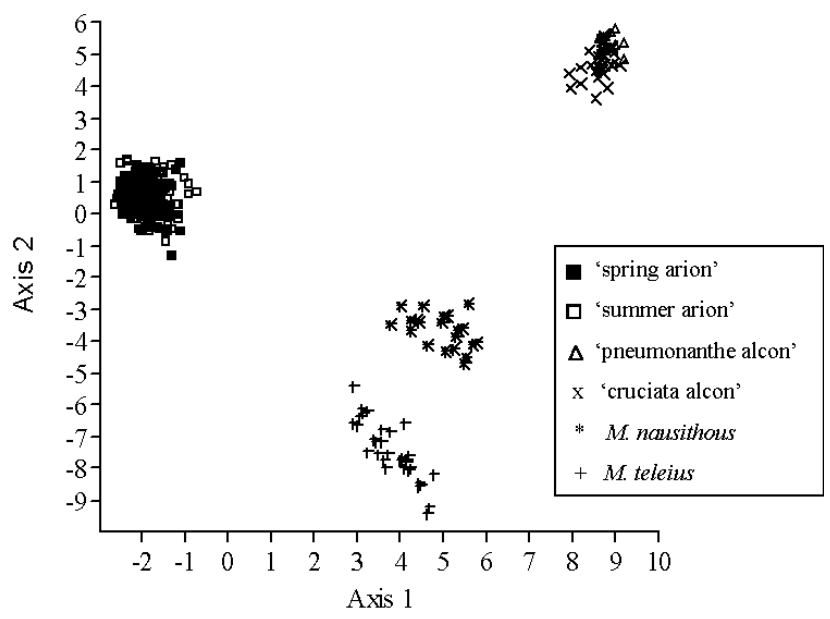

Fig. 6. The results of PCA. Each symbol represents one sample in the reduced space by variances. The first two axes explain 60.5 percent of the total variance. $M d h, G p d h$ and $H k$ loci have the highest loading in Axis $1 . M d h, H k$ and Gpdh loci have the highest loading in Axis 2. 


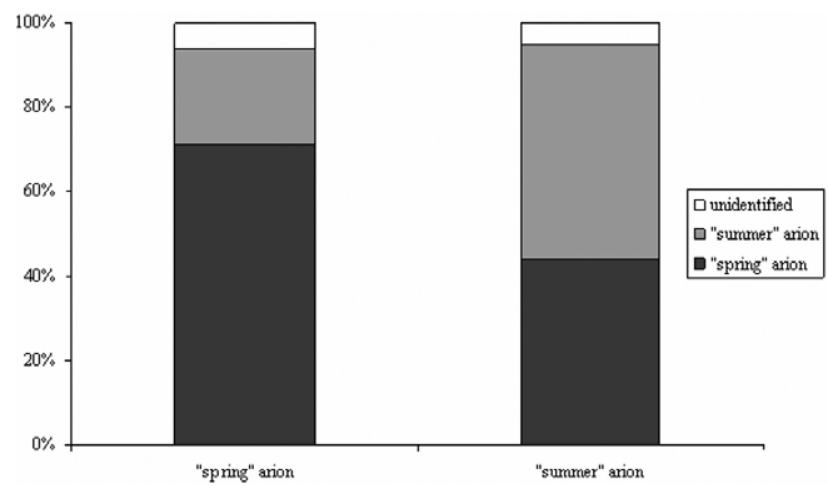

Fig. 7. The results of the assignment test.

The results of the PCA analyses fully confirmed our results discussed so far (Fig. 6). While $M$. arion samples exhibited overlapping clouds of points the other $\mathrm{Macu}$ linea species were separated evidently in the reduced space of variables. The two axes explained $60.5 \%$ of the total variation. The first axis was predominantly determined by the $M d h, G p d h$ and $H k$ loci. The second axis was mostly affected by the allele frequency distribution at the $M d h, H k$ and $G p d h$ locus.

In the assignment test (Fig. 7) there were individuals in both types approximately at the same percentage (6.21 and $5.24 \%$, respectively) that could not be classified. The program grouped the "spring arion" individuals correctly to a higher extent $(71.19 \%)$ than the "summer type" ones $(43.95 \%)$. It was the consequence of the fact that the genetic composition of the "spring arion" samples was relatively homogenous, while there were considerable differences among the "summer arion" samples.

\section{DISCUSSION}

\section{The level of genetic diversity}

Maculinea species are generally less polymorphic than other lycaenid butterflies (e.g. Plebejus argus: Thomas et al., 1998; Polyommatus coridon, P. bellargus, P. icarus: Schmitt, 1999; Schmitt et al., 2002, 2003; Schmitt \& Hewitt, 2004; Schmitt \& Seitz, 2001, 2002a, b; Aricia artaxerxes: Aagard et al., 2002; Pecsenye et al., 2007; Aricia agestis: Habel \& Schmitt, 2009; Cupido minimus: Habel \& Schmitt, 2009). Our results are comparable with those of other surveys which also found a relatively low level of variation at the loci investigated (Gadeberg \& Boomsma, 1997; Bereczki et al., 2005; Pecsenye et al., 2007).

The level of polymorphism was the highest in $M$. arion compared to the other sampled Maculinea species. This is probably due to its higher dispersal ability. Maculinea butterflies are generally regarded as sedentary species, although their mobility seems to be stronger than previously thought (Thomas, 1995; Munguira \& Martin, 1997). The dispersal ability of $M$. arion is the highest of all Maculinea species (Pajari, 1992; Geissler \& Settele, 1990; Settele et al., 1996). Our field experience also supports this observation (Árnyas, 2007; Árnyas et al., unpubl. data). We have also observed a regular movement of $M$. arion butterflies between steppic grassland patches separated by sparsely forested areas in the Aggtelek karst area (field observations of Z. Varga). As a consequence of their higher dispersal ability, their reproductive opportunities can become wider. Therefore, they probably have a more intense gene flow, which can partly balance the effect of genetic drift. Additionally, their larvae are able to survive starvation up to three weeks after the desertation of ant workers, until the nest is recolonized by a neighbouring Myrmica colony (Thomas \& Lewington, 2010). It is possible that the high mobility of $M$. arion is associated with this kind of larval survival strategy. A sufficient quantity of ant brood is necessary for the sustenance of larvae thus imagos fly over large areas and spread across habitat patches. Therefore, they are not present at high density in any particular patch. Additionally, in contrast to other Maculinea species, it is only exceptional that more than one $M$. arion larva can develop in a single host ant nest (Thomas \& Lewington, 2010). All this can counterbalance the stochasticity of larval adoption.

As for the level of polymorphism in $M$. arion it appeared slightly higher in the "spring arion" than in the "summer type" populations, but there were no significant differences between the two types concerning their genetic diversity.

\section{The genetic structure}

The differences between the putative subspecies of $M$. arion accounted for a lower percentage of the total level of differentiation. The scale of separation between the "spring" and the "summer arion" was similar to the level of differentiation between the "pneumonanthe" and the "cruciata type" of $M$. alcon. Molecular data indicate that the latter two are not separated at the species level and they represent local ecological adaptations (Als et al., 2004; Pech et al., 2004; Bereczki et al., 2005; Fric et al., 2007; Pecsenye et al., 2007).

The level of differentiation among populations (the spatial component of variation) was lower than that among the samples from the same population (the temporal component of variation). That means a considerable fluctuation in allele frequencies occurred among generations. These findings are consistent with our former results (Bereczki et al., 2005) and imply a strong effect of genetic drift, which is expected considering the life cycle of Maculinea species. It is also supported by field experience (Korosi et al., 2005) which revealed that the population size of $M$. arion fluctuates considerably despite the fact that the habitat and abundance of food plant appears stable.

\section{ESUs}

Neither of the ESU criteria is realized in the case of the two phenologically differentiated sets of populations of M. arion; therefore, the "spring" and "summer arion" cannot be considered as ESUs. The two sets of populations were not separated evidently on the basis of allozyme studies. Additionally, our data only weakly support the ecological isolation of the two forms, since there is a certain extent of overlapping in the initial food plant 
usage of the "spring" and "summer arion" due to the relatively long flowering period of different Thymus species, and also because the "summer arion" can simultaneously use Thymus spp. and Origanum vulgare. Nevertheless, differences in food plant use also imply some difference in habitat preference. The "spring arion" mostly feeds on xerophilous "steppic" Thymus species (e.g. Thymus pannonicus), while the "summer arion" occupying heath-like acidic habitats also utilize Thymus pulegoides (oviposition observed by Z. Varga). Although the two forms generally have different habitat preferences locally they often co-occur (Tóth \& Bereczki, pers. obs.). These sympatric populations are phenologically more or less isolated. Nevertheless, there are non-evolutionary reasons for attributing conservation value to different sets of populations (Moritz, 1994). In the case of the two forms of $M$. arion this could be the phenological separation and the differences in habitat preference which can imply different types of habitat conservation (i.e. short-grass steppic vs. heath-like habitats). Although we do not have sufficient information regarding the status of the two forms of $M$. arion, we have to strive to preserve their genetic variability as widely as possible. Recently genetic variation has been ascribed great importance in terms of the climate change, as larger variation may facilitate the adaptation to changes in climate. Nevertheless, it would be important to carry out further studies to enhance our knowledge of the ecological characteristics of the two types of $M$. arion better and be able to work out more effective conservation strategies.

ACKNOWLEDGEMENTS. The study was supported by the MacMan EVK2-CT-2001-00126 project. Grateful acknowledgements are due to L. Peregovits and S. Szabó for collecting samples. The technical assistance of $\mathrm{V}$. Mester with the electrophoretic work is greatly appreciated as is the support of the Nature Conservation Authorities of Hungary.

\section{REFERENCES}

Aagaard K., Hindar K., Pullin A.S., James C.H., Hammarstedt O., Balstad T. \& Hanssen O. 2002: Phylogenetic relationships in brown argus butterflies (Lepidoptera: Lycaenidae: Aricia) from north-western Europe. Biol. J. Linn. Soc. 75: $27-37$.

Als T.D., Vila R., Kandul N.P., Nash D.R., Yen S.-H., Hsu Y.-F., Mignault A.A., Boomsma J.J. \& Pierce N.E. 2004: The evolution of alternative parasitic life histories in large blue butterflies. Nature 432: 386-390.

Anonymus 1993: Council Directive 93 35/EEC of 14 June 1993. OJ No. L151, 23.6.93. pp. 32-37.

ÁRnYas E.M. 2007: Population structure, dynamics and egglaying preference in a threatened butterfly (Maculinea alcon, Lepidoptera: Lycaenidae). PhD thesis, Debrecen.

BÁLInt Z. 1996: A Kárpát-medence nappali lepkéi 1. Pillangófélék, fehérlepkefélék, boglárkalepke-félék, mozaiklepke-félék. [The Butterflies of the Carpathian Basin. 1. Papilionidae, Pieridae, Lycaenidae, Riodinidae.] Magyar Madártani és Természetvédelmi Egyesület, Budapest, pp. 130-133.

Balletto E., Bonelli S., Settele J., Thomas J.A., Verovnik R. \& Wahlberg N. 2010: Case 3508 Maculinea Van Eecke, 1915 (Lepidoptera: Lycaenidae): proposed precedence over Phengaris Doherty, 1891. Bull. Zool. Nomencl. 67: 129-132.
Bereczki J., Pecsenye K., Peregovits L. \& Varga Z. 2005: Pattern of genetic differentiation in the Maculinea alcon species group (Lepidoptera, Lycaenidae) in Central Europe. J. Zool. Syst. Evol. Res. 43: 157-165.

Cavalli-Sforza L. \& Edwards A. 1967: Phylogenetic analysis: models and estimation procedures. Evolution. 21: 550-570.

Crandall K.A., Bininda-Emonds O.R.P., Mace G.M. \& Wayne R.K. 2000: Considering evolutionary processes in conservation biology. Trends Ecol. Evol. 15: 290-295.

Dizon A.E., Lockyer C., Perrin W.F., Demaster D.P. \& Sisson J. 1992: Rethinking the Stock Concept: A Phylogeographic Approach. Conserv. Biol. 6: 24-36.

Elmes G.W. \& Thomas J.A. 1987a: Die Biologie und Ökologie der Ameisen der Gattung Myrmica. In Geiger W. (ed.): Tagfalter und ihre Lebensräume: Arten, Gefährdung, Schutz. Schweizerische Bund für Naturschutz, Basel, pp. 404-409.

Elmes G.W. \& Thомas J.A. 1987b: Die Gattung Maculinea. In Geiger W. (ed.): Tagfalter und ihre Lebensräume: Arten, Gefährdung, Schutz. Schweizerische Bund für Naturschutz, Basel, pp. 354-368.

Elmes G.W., Thomas J.A. \& Wardlaw J.C. 1991a: Larvae of Maculinea rebeli, a large-blue butterfly, and their Myrmica host ants: wild adoption and behaviour in ant-nests. J. Zool. 223: 447-460.

Elmes G.W., Wardlaw J.C. \& Thomas J.A. 1991b: Larvae of Maculinea rebeli, a large-blue butterfly and their Myrmica host ants: patterns of caterpillar growth and survival. J. Zool. 224: 79-92.

Elmes G.W., Thomas J.A., Hammarstedt O., Munguira M.L., Martin J. \& Van Der Made J. 1994: Differences in host-ant specificity between Spanish, Dutch and Swedish populations of the endangered butterfly, Maculinea alcon (Denis et Schiff.) (Lepidoptera). Memor. Zool. 48: 55-68.

Excoffier L., Smouse P.E. \& Quattro J.M. 1992: Analysis of molecular variance inferred from metric distances among DNA haplotypes: Application to human mitochondrial DNA restriction data. Genetics 131: 479-491.

Fleishman E., Thomson J.R., Mac Nally R., Murphy D.D. \& FAY J.P. 2005: Using indicator species to predict species richness of multiple taxonomic groups. Conserv. Biol. 19: $1125-1137$.

Fric Z., Wahlberg N., Pech P. \& Zrzavy J. 2007: Phylogeny and classification of the Phengaris-Maculinea clade (Lepidoptera: Lycaenidae): total evidence and phylogenetic species concepts. Syst. Entomol. 32: 558-567.

Gadeberg R.M.E. \& Boomsma J.J. 1997: Genetic population structure of the large blue butterfly Maculinea alcon in Denmark. J. Insect Conserv. 1: 99-111.

Geissler S. \& Settele J. 1990: Zur Ökologie und zum Ausbreitungsverhalten von Maculinea nausithous, Bergsträsser 1779 (Lepidoptera, Lycaenidae). Verh. Westdeut. Entomol. Tag 1989: 187-193.

Goffart P. 1997: Libellules et Papillons en Wallonie. Université Catholique de Louvain-la-Neuve, Louvain-la-Neuve, 33 pp.

GoudET J. 1995: FSTAT (Version 1.2): A computer program to calculate F-Statistics. J. Hered. 86: 485-486.

Gozmány L. 1968: Nappali lepkék - Diurna. Magyarország Állatvilága [Fauna Hungariae] XVI (15.) Akadémiai Kiadó, Budapest, $88 \mathrm{pp}$.

Habel J.C. \& Schmitt T. 2009: The genetic consequences of different dispersal behaviours in Lycaenid butterfly species. Bull. Entomol. Res. 99: 513-523.

Hammer Ø., Harper D.A.T. \& Ryan P.D. 2001: PAST: Paleontological Statistics Software Package for education and data analysis. Palaeontol. Electron. 4(1): 9 pp. 
Korosi A., Peregovits L., Orvossy N., Vozar A. \& Kassai F. 2005: Studying the population structure of Maculinea arion ligurica. In: Studies on the Ecology and Conservation of Butterflies in Europe. Vol. 2: Species Ecology along a European Gradient: Maculinea Butterflies as a Model. Proceedings of the Conference held in UFZ Leipzig. p. 133.

LAMBECK R.J. 1997: Focal species: A multi-species umbrella for nature conservation. Conserv. Biol. 11: 849-856.

Moritz C. 1994: Defining evolutionarily-significant-units for conservation. Trends Ecol. Evol. 9: 373-375.

Munguira M.L. \& Martin J. 1997: Action Plan for the Maculinea Butterflies in Europe. Council of Europe, Strasbourg, pp. 1-96.

New T.R. 1997: Are Lepidoptera an effective "umbrella group" for biodiversity conservation? J. Insect Conserv. 1: 5-12.

PaETKAU D. 1999: Using genetics to identify intraspecific conservation units: a critique of current methods. Conserv. Biol. 13: 1507-1509.

Paetkau D., Calvert W., Stirling I. \& Strobeck C. 1995: Microsatellite analysis of population structure in Canadian polar bears. Mol. Ecol. 4: 347-354.

Pajari M. 1992: An Estimation of the Population Size and Habitat Demands of Maculinea arion During the Summer of 1990 in Liperi, North Karelia. Graduate thesis, University of Joensuu, 27 pp. +10 appendices [in Finnish].

Pech P., Fric Z., Konvicka M. \& ZrZavy J. 2004: Phylogeny of Maculinea blues (Lepidoptera: Lycaenidae) based on morphological and ecological characters: evolution of parasitic myrmecophily. Cladistics 20: 362-375.

Pecsenye K., Bereczki J., Tihanyi B., Toth A., Peregovits L. \& VARGA Z. 2007: Genetic differentiation among the Maculinea species (Lepidoptera: Lycaenidae) in eastern Central Europe. Biol. J. Linn. Soc. 91: 11-21.

Piry S., Alapetite A., Cornuet J.-M., Paetkau D., Baudouin L. \& Estoup A. 2004: GENECLASS2: A Software for genetic assignment and first-generation migrant detection. J. Hered. 95: 536-539.

Pritchard J.K., Stephens M. \& Donnelly P. 2000: Inference of population structure using multilocus genotype data. Genetics 155: 945-959.

Pueffoy E.B. 1953: An unpublished account of experiments carried out at East Farleigh, Kent, in 1915 and subsequent years on the life history of Maculinea arion, the large blue butterfly. Proc. R. Entomol. Soc. Lond. 28: 160-162.

RAYMOND M. \& Rousset F. 1995a: An exact test for population differentation. Evolution 49: 280-1283.

RAYMond M. \& Rousset F. 1995b: GENEPOP (Version 1.2) Population genetics software for exact tests and ecumenicism. J. Hered. 86: 248-249.

Ryder O.A. 1986: Species conservation and systematics: the dilemma of subspecies. Trends Ecol. Evol. 1: 9-10.

Sснміт T. 1999: Phylogeographie europäischer Tagfalter basierend auf populations-genetischen Analysen. $\mathrm{PhD}$ thesis, University of Mainz, $200 \mathrm{pp}$.

Schmitt T. \& HewitT G.M. 2004: The genetic pattern of population threat and loss: a case study of butterflies. Mol. Ecol. 13: 21-31.

Schmitt T. \& SeItz A. 2001: Allozyme variation in Polyommatus coridon (Lepidoptera: Lycaenidae): identification of ice-age refugia and reconstruction of post-glacial expansion. J. Biogeogr. 28: 1129-1136.

Schmitt T. \& Seitz A. 2002a: Influence of habitat fragmentation on the genetic structure of Polyommatus coridon (Lepidoptera: Lycaenidae): implications for conservation. Biol. Conserv. 107: 291-297.
Schmitt T. \& Seitz A. 2002b: Postglacial distribution area expansion of Polyommatus coridon (Lepidoptera: Lycaenidae) from its Ponto-Mediterranean glacial refugium. Heredity 89: $20-26$.

Schmitt T., Giesl A. \& Seitz A. 2002: Postglacial colonisation of western Central Europe by Polyommatus coridon (Poda 1761) (Lepidoptera: Lycaenidae): evidence from population genetics. Heredity 88: 26-34.

Schmitt T., Giessl A. \& Sertz A. 2003: Did Polyommatus icarus (Lepidoptera: Lycaenidae) have distinct glacial refugia in southern Europe? Evidence from population genetics. Biol. J. Linn. Soc. 80: 529-538.

Schneider S., Roessli D. \& Excoffier L. 2000: Arlequin ver. 2.000: A Software for Population Genetic Data Analysis. Genetics and Biometry Laboratory, University of Geneva.

Settele J. \& Kuhn E. 2009: Insect conservation. Science 325: $41-42$.

Settele J., Margules C., Poschold P. \& Henle K. 1996: Species Survival in Fragmented Landscapes. Kluwer, Dordrecht.

Shrader-Frechette K.S. \& McCoy E.D. 1993: Method in Ecology. Strategies for Conservation. Cambridge University Press, Cambridge, 344 pp.

Sneath P.H. \& SoKal R.R. 1973: Numerical Taxonomy. W.H. Freeman, San Francisco, 573 pp.

Spitzer L., Benes J., Dandova J., Jaskova V. \& Konvicka M. 2009: The Large Blue butterfly, Phengaris [Maculinea] arion, as a conservation umbrella on a landscape scale: The case of the Czech Carpathians. Ecol. Indicat. 9: 1056-1063.

Swofford D.L. \& Selander R.B. 1981: BIOSYS-1: a FORTRAN program for the comprehensive analysis of electrophoretic data in population genetics and systematics. J. Hered. 72: 281-283.

SzABÓ R. 1956: Magyarország Lycaenidái - Die Lycaeniden Ungarns. Folia Entomol. Hungar. 9: 254-362.

TARTAlly A. 2008: Myrmecophily of Maculinea Butterflies in the Carpathian Basin (Lepidoptera: Lycaenidae). $\mathrm{PhD}$ thesis, University of Debrecen, $97+136 \mathrm{pp}$. [in Hungarian].

TAx M.H. 1989: Atlas van de Nederlandse Dagvlinders. De Vlinderstichting and s'-Graveland: Stichting tot Behoud van Natuurmonumenten, Wageningen, 248 pp.

Thomas C.D., HiLl J.K. \& Lewis O.T. 1998: Evolutionary consequences of habitat fragmentation in a localised butterfly. $J$. Anim. Ecol. 67: 485-497.

Thomas J. \& Lewington R. 2010: The Butterflies of Britain and Ireland. British Wildlife Publishing, Dorset, 288 pp.

Thомаs J.A. 1976: The ecology of the large blue butterfly. Annu. Rep. Inst. Terr. Ecol. 1976: 8-25.

THOMAS J.A. 1995: The ecology and conservation of Maculinea arion and other European species of large blue butterfly. In Pullin A.S. (ed.): Ecology and Conservation of Butterflies. Chapman \& Hall, London, pp. 180-196.

Thomas J.A., Elmes G.W., Wardlaw J.C. \& Woyciechowski M. 1989: Host specificity among Maculinea butterflies in Myrmica ant nests. Oecologia 79: 452-457.

Thomas J.A., Clarke R.T., Elmes G.W. \& Hochberg M.E. 2000: Population Dynamics in the Genus Maculinea (Lepidoptera: Lycaenidae). In Dempster J.P. \& McLean F.G. (eds): Insect Population Dynamics. Chapman \& Hall, London, pp. 261-290.

Thomas J.A., Simcox D.J. \& Clarke R.T. 2009: Successful conservation of a threatened Maculinea butterfly. Science 325: 80-83.

ThOMAS J.A. \& WardLAW J.C. 1992: The capacity of a Myrmica ant nest to support a predacious species of Maculinea butterfly. Oecologia 91: 101-109. 
Van Swaay C., Warren M. \& Grill A. 1998: Convention on the Conservation of European Wildlife and Natural Habitats: Threatened Butterflies in Europe. Strasbourg, pp. 4-95.

VARGA Z. 2003: Post-glacial dispersal strategies of Orthoptera and Lepidoptera in Europe and in the Carpathian Basin. In Reemer M., Helsdingen P.V. \& Kleukers R. (eds): Proceedings of the 13th International Colloquium of the European Invertebrate Survey. European Invertebrate Survey, Leiden, pp. 93-105.

Vogler A.P., Knisley C.B., Glueck S.B., Hill J.M. \& Desalle R. 1993: Using molecular and ecological data to diagnose endangered populations of the puritan tiger beetle Cicindela puritana. Mol. Ecol. 2: 375-383.
WAPLES R.S. 1998: Evolutionarily significant units, distinct population segments, and the endangered species act: Reply to Pennock and Dimmick. Conserv. Biol. 12: 718-721.

WeIr B.S. 1996: Genetic Data Analysis II: Methods for Discrete Population Genetic Data. Sinauer Assoc., Sunderland, 445 pp.

Wright S. 1978: Evolution and the Genetics of Populations. Vol. 4. Variability Within and Among Natural Populations. University of Chicago Press, Chicago, $590 \mathrm{pp}$.

WynhofF I. 1998: Review: The recent distribution of the European Maculinea species. J. Insect Conserv. 2: 15-27.

Received January 13, 2011; revised and accepted May 5, 2011

APPENDIX 1. Sample sites (number of individuals / year).

\begin{tabular}{|c|c|c|c|c|c|c|c|c|c|}
\hline \multirow{2}{*}{ Taxa } & \multirow{2}{*}{ Sample sites (No. / Lab.) } & \multirow{2}{*}{ Abb. } & \multicolumn{7}{|c|}{ Year of sampling } \\
\hline & & & 2000 & 2001 & 2002 & 2003 & 2004 & 2005 & 2006 \\
\hline \multirow{3}{*}{ M. arion "spring type" } & Jósvafö-plateau (1) & Jfo & 15 & & & 22 & 25 & 44 & 14 \\
\hline & Jósvafö-Szőlőhegy (2) & Szh & & & & & & 16 & \\
\hline & Teresztenyei- plateau (3) & Ter & & & & & & 16 & 25 \\
\hline \multirow{5}{*}{ M. arion "summer type" } & Kaszonyi-hill (4) & $\mathrm{Kh}$ & 11 & 11 & 19 & 22 & & & \\
\hline & Vérteskozma (5) & $\mathrm{Vk}$ & & & 11 & 20 & & & \\
\hline & Lake Gyilkos (6) & Gy & & & 14 & & 26 & & \\
\hline & Aggtelek (7) & Agg & & & & 17 & 23 & 35 & 22 \\
\hline & Torockószentgyörgy (8) & Tor & & & & & 17 & & \\
\hline M. alcon "pneumonanthe type" & Fülesd $(\mathrm{P})$ & PFul & & & & & 24 & & \\
\hline M. alcon "cruciata type" & Jósvafö-Tohonya (C) & CToh & & & & & 35 & & \\
\hline M. teleius & Aggtelek (T) & TAgg & & & & & 26 & & \\
\hline M. nausithous & Szomoróc (N) & NSzo & & & & & 59 & & \\
\hline
\end{tabular}

No. / Lab. - number / letter of populations on the map (Fig. 1); Abb. - abbreviations of the populations (Figs 2 , 4 and 5). 